\title{
INFLUENCE OF SOME PRESERVATIVE SOLUTIONS ON VASE LIFE AND POSTHARVEST QUALITIES OF LIMONIUM CUT FLOWERS
}

\author{
E.A. Khella ${ }^{*}$, A.M. Abd-ElMoniem ${ }^{*}$ and A.M.B. Mohamed ${ }^{* *}$ \\ * Ornamental Plants \& Landscape Gardening Res. Dept., Hort. Res. Inst., Agric. Res. Cent., Egypt. \\ ** Department of Plant Pathology Res., ARC, Giza, Egypt.
}

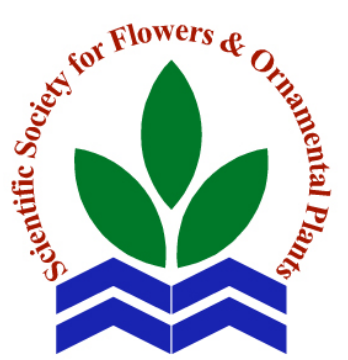

Scientific J. Flowers \& Ornamental Plants, 5(1):89-103 (2018).

Received: 25/2/2018 Accepted: 8/3/2018

ABSTRACT: The present study was conducted at the Postharvest Lab. of Ornamental Plants and Landscape Gardening Res. Dept., Hort. Res. Inst., Giza, Egypt in March of 2016 and 2017 seasons, to examine the effect of some pulsing solutions on improving the quality of limonium cut flowers. Limonium cut flowers were pulsed in silver thiosulfate (STS) at $500 \mathrm{mg} / \mathrm{l}$ for $1 / 4$ and $1 / 2 \mathrm{~h}$, silver nitrate $\left(\mathrm{AgNO}_{3}\right)$ at $500 \mathrm{mg} / \mathrm{l}$ for $1 / 4$ and $1 / 2 \mathrm{~h}, \mathrm{AgNO}_{3}$ at one g/l for $1 / 4$ and $1 / 2 \mathrm{~h}$, sodium benzoate at $250 \mathrm{mg} / \mathrm{l}$ for 12 and $24 \mathrm{~h}$, sodium benzoate at 500 $\mathrm{mg} / \mathrm{l}$ for 12 and $24 \mathrm{~h}$, daminozide at $25 \mathrm{mg} / \mathrm{l}$ for 12 and $24 \mathrm{~h}$ and daminozide at $50 \mathrm{mg} / \mathrm{l}$ for 12 and $24 \mathrm{~h}$ followed by transferring to a holding solution 8-hydroxyqunoline sulphate (HQS) at $200 \mathrm{mg} / \mathrm{l}+$ sucrose $(20 \mathrm{~g} / \mathrm{l})$. Distilled water was used as a control treatment. The obtained results indicated that treatment of Limonium sinuatum cv. Girlie Wings cut flowers treated by STS at $500 \mathrm{mg} / \mathrm{l}$ for $1 / 2 \mathrm{~h}$ enhanced water uptake, relative fresh weight, dry weight percentage of cut flowers, floret opening percentage, pigments content, total carbohydrate percentage and total phenols as well as inhibiting growth of all isolated microorganisms and improved quality of flowers, followed by cut flowers treated with STS at $500 \mathrm{mg} / \mathrm{l}$ for $1 / 4 \mathrm{~h}$ then $\mathrm{AgNO}_{3} 500 \mathrm{mg} / \mathrm{l}$ for $1 / 2 \mathrm{~h}$.

Key words: Limonium sinuatum, silver thiosulfate (STS), silver nitrate $\left(\mathrm{AgNO}_{3}\right)$, sodium benzoate, daminozide, sucrose, 8hydroxyqunoline sulphate (8-HQS).

\section{INTRODUCTION}

Limonium is a genus of ornamental plants belongs to the family Plumbaginaceae. It has a sub-cosmopolitan appropriation in Europe, Asia, Africa, Australia, North America, Canary Islands and the Mediterranean. There are various shades of flowers, for example, white, blue, rose, red, coral, light yellow, purple and mauve. Limonium sinuatum, usually known as static, ocean lavender, indent leaf bog rosemary, ocean pink, wavy leaf and ocean lavender, it is herbaceous enduring and channel molded flowers in summer (Wikipedia, 2017). Phenomenal as a crisp cut flower and useful for dried bloom plans. The plant is garden employments of blended fringes, shake gardens, cut bloom gardens, glades and cutting patio nurseries.

The life span of the cut blossom is an essential issue today. Additionally, the most vital compounding factor in cut flowers is ethylene creation and blockage of xylem vessels via air and microorganism (Elgimabi and Ahamed, 2009 and Elgimabi, 2011). Hashemabadi et al. (2015) found that microorganisms and microbes that develop in the vase arrangement, hinder the stem end and decrease water take-up by the blooms, in addition, the generation of synthetic aggravates that lead to vascular blockage and 


\section{E.A. Khella et al.}

along these lines diminish the vase life of cut flowers.

Distinctive substances can be utilized as an additive in the answer for delaying the vase life of cut flowers, lessen microbial proliferation and vascular blockage, increase water take-up of the stem and stop the hurtful impact of ethylene.

Hydroxyqunoline combination with sucrose improved the postharvest quality of gladiolus spikes (Beura et al., 2001). Pun and Ichimura (2003) showed that 8-HQS treatment was more effective when sucrose was coupled with it. Vigna et al. (1999) mentioned that $2.5 \%$ sucrose $+150 \mathrm{mg} / \mathrm{l}$ 8HQS increased keeping quality in Limonium sinuatum. In Dendrobium cut flowers, holding solutions containing 8-HQS + sucrose extended the vase life and increased flower quality, water consumption, fresh weight, flower freshness, and reduced respiration rate and physiological weight loss (Dineshbabu et al., 2002). Yann et al. (2000) showed that $10 \%$ sucrose $+200 \mathrm{ppm} 8$-HQS prolonged vase life and increases ornamental value of Limonium. Also, sucrose with 8HQS maximized vase life for flowers and maintained stem fresh weight of waxflower (Dung et al., 2017). The preservative composed of 8-HQC and sucrose markedly improved flower longevity of clematis flowers (Rabiza et al., 2017). Hydroxyqunoline prevents the growth of microorganisms in xylem vessels, maintaining water uptake and extending flower vase life (Asrar, 2012). Abdul-Wasea (2012) found that 200 ppm 8-HQS combined with $2 \%$ sucrose solution have the potential to be used as a commercial cut flower preservative solution to delay flower senescence, enhance post-harvest quality and prolong the vase life of cut snapdragon flowers.

The use of ethylene antagonist silver thiosulfate solution (STS) will therefore allow for a better adjustment of flowers supply to the requirements of the market. Asrar (2012) showed that pulsing the spikes with $0.2 \mathrm{mM}$ silver thiosulfate (STS) for $1 \mathrm{~h}$ treatments had improved the keeping quality and vase life of the cut flowers comparing to control ones of cut snapdragon flowers. Gul and Inayatullah (2013) found that in Narcissus pseudonarcissus flowers pulse treatment of spikes with STS $(0.5 \mathrm{mM}, 1 \mathrm{~h})$ increased solution uptake, maintained high fresh and dry mass of flowers. Suong et al. (2017) revealed that STS was the most effective pretreatment solution, significantly extending the vase life from 11.8 days (control) to 19.9 days, retaining the initial fresh weight and a positive water balance for longer and inhibiting microbial growth in the vase. STS also enhanced the water uptake rate, and maintained the high chlorophyll and soluble sucrose contents in the leaves of cut rose flowers. Bang et al. (1999) found that pulseding with STS $(0.5 \mathrm{mM})$ for 45 minutes of 'Raktagandha' roses was found to be best for improving post harvest life and quality. Sodium benzoate as an antifungal compound reduces microorganisms' activity and bacterial contamination in vase solution. Ketsa and Sribunma (1985) showed that pulsing treatment with sodium benzoate at $300 \mathrm{mg} \mathrm{l}^{-1}$ concentration for $24 \mathrm{~h}$ gave maximum vase life of cut rose cv. 'Christian Dior' flower. Davood et al. (2012) revealed that $250 \mathrm{mg} \mathrm{l}^{-1}$ of sodium benzoate was the most effective on vase life of rose cut flowers and reduced ethylene production.

Silver nitrate $\left(\mathrm{AgNO}_{3}\right)$ is one of the most common forms of silver salts used in commercial flower preservative solutions and mostly used as ethylene binding inhibitor. Darras and Pompodakis (2010) reported that pulsing with 20 or $40 \mathrm{mg} \mathrm{l}^{-1}$ $\mathrm{AgNO}_{3}$ for $24 \mathrm{~h}$ extended vase life by 1.6 and 1.9 days, respectively, compared to the control. Pulsing cut roses for 10-20 mint with $\mathrm{AgNO}_{3}$ improved the vase life up to 6.0 and 5.3 days, respectively (Reddy and Raju, 1988). Mohy Eldeen (2012) found that significant improvement in vase life of rose cut flowers occurred when pulsed with 30 ppm $\left(\mathrm{AgNO}_{3}\right)$. Pulsing with $\left(\mathrm{AgNO}_{3}\right)$ strikingly enhanced vase life and solution uptake in rose cut flowers (Singh and Tiwari, 2002). Amit et al. (2013) stated that $\mathrm{AgNO}_{3}$ 
(25 ppm) was the best preservatives in diameter of florets and fresh weight of gladiolus flower.

Daminozide (B-9) is a plant growth retardant, can hinder plant tissues gibberellins biosynthesis, thereby inhibiting the growth of cut flower plants and extend the life of cut flowers after the cutting. Kahar (2008) found that single application of B-9 at $2500 \mathrm{ppm}$ in chrysanthemum delayed the time of flowering and improved the synchrony of flowering and double the vase life. Application of daminozide at $2500 \mathrm{ppm}$ improved vase life (Jeyakumar et al., 2016).

In this study endeavors have been made to broaden the vase life of limonium flowers by the utilization of various chemical compounds at different concentrations, and by utilizing synthetic substances effectively accessible in the nearby market.

\section{MATERIALS AND METHODS}

The experimental trial research was carried out at Ornamental Plants and Landscape Gardening Research Dept., Hort. Res. Inst. ARC, Giza, Egypt in throughout two successive seasons 2016 and 2017.

\section{Plant material:}

Limonium sinuatum cv. Girlie Wings cut flowers were purchased from the local commercial green-houses of Floramix Farm (El-Mansouria, Giza). The flowering stems were cut in the early morning with the stem length of $80 \mathrm{~cm}$, at basal florets opening and directly wrapped in groups and transported to the laboratory within nearly 2 hours. Flowers were precooled by placing in ice cold water for one hour to remove the effect of high field heat. $3 \mathrm{~cm}$ of stem bases were recut under water to avoid air embolism before treatment.

\section{First experiment:}

The cut flowers were divided into four groups. The first group was pulsed in preservative solution containing silver thiosulfate (STS), the second group in silver nitrate $\left(\mathrm{AgNO}_{3}\right)$, the third group in sodium benzoate and the fourth one in daminozide.
These four groups were held in a preservative solution consisting of 8hydroxyqunoline sulphate $(200 \mathrm{mg} / \mathrm{l})$ + sucrose (20 g/l) in addition to distilled water (control).

The treatments were evaluated as follows:

$\mathrm{T} 1=$ Distilled water (control).

T2= Pulsing in STS at $500 \mathrm{mg} / \mathrm{l}$ for $1 / 4$ hour.

T3= Pulsing in STS at $500 \mathrm{mg} / \mathrm{l}$ for $1 / 2$ hour.

$\mathrm{T} 4=$ Pulsing in $\mathrm{AgNO}_{3} 500 \mathrm{mg} / \mathrm{l}$ for $1 / 4$ hour.

T5= Pulsing in $\mathrm{AgNO}_{3} 500 \mathrm{mg} / \mathrm{l}$ for $1 / 2$ hour.

$\mathrm{T} 6=$ Pulsing in $\mathrm{AgNO}_{3} 500 \mathrm{mg} / \mathrm{l}$ for $1 / 4$ hour.

$\mathrm{T} 7=$ Pulsed in $\mathrm{AgNO}_{3} \mathrm{~g} / \mathrm{l}$ four 1/2 hour.

T8= Pulsing in sodium benzoate at $250 \mathrm{mg} / \mathrm{l}$ for 12 hours.

T9= Pulsed in sodium benzoate at $250 \mathrm{mg} / \mathrm{l}$ for 24 hours.

$\mathrm{T} 10=$ Pulsing in sodium benzoate at 500 $\mathrm{mg} / \mathrm{l}$ for 12 hours.

$\mathrm{T} 11=$ Pulsing in sodium benzoate at 500 $\mathrm{mg} / \mathrm{l}$ for 24 hours.

$\mathrm{T} 12=$ Pulsing in daminozide at $25 \mathrm{mg} / \mathrm{l}$ for 12 hours.

$\mathrm{T} 13=$ Pulsing in daminozide $25 \mathrm{mg} / \mathrm{l}$ for 24 hours.

T14= Pulsing in daminozide $50 \mathrm{mg} / \mathrm{l}$ for 12 hours.

$\mathrm{T} 15=$ Pulsing in daminozide $50 \mathrm{mg} / \mathrm{l}$ for 24 hours.

The cut flowers were placed in a flask or bottle $(1000 \mathrm{ml})$ containing $450 \mathrm{ml}$ of holding preservative solution (3 flower heads/flask). Each flask was covered at its surface with cellophane wrap to prevent evaporation during the vase life period and till the end of experiment under the room temperature. The following traits were studied:

- Vase life (longevity): Vase life was determined as the number of days to wilting of flowers. 


\section{E.A. Khella et al.}

- Water uptake and water loss (g/inflorescence): accumulative water uptake and loss were recorded for the entire period of vase life of the inflorescence stem.

- Floret opening percentage was calculated as a percentage of opened florets from all the florets on the cut cluster spike (inflorescence) at the end of longevity.

- Relative fresh weight (\%): Relative fresh weight of stems was calculated using the following formula (He et al., 2006):

Fresh weight of stem in

RFW (\%) $=\frac{\text { mentioned day } \times 100}{\text { Fresh weight of stems in zero }}$ days

- Dry matter: Dry matter percentage of cut flowers was calculated by the following equation: DM (\%) = dry weight/fresh weight $\times 100$ (Hashemabadi et al., 2015).

Chemical analyses: Chlorophyll a, chlorophyll b and carotenoids (mg/100 g f.w.) were determined in the fresh leaf samples at the end of longevity and measured according to Lichtenthaler and Wellburn (1985). Total carbohydrates (\%) content were determined according to A.O.A.C. (1995).

Anthocyanin content (\%) in flowers was determined colorimetrically according to Fuleki and Francis (1968).

Phenols content in the leaves: $\mathrm{mg} / 100 \mathrm{~g}$ f.w. according to A.O.A.C. (1990). Indoles content in the leaves: $\mathrm{mg} / 100 \mathrm{~g}$ f.w. as recorded by Larsen et al. (1962) and Salim et al. (1978) and the concentration were calculated as mg indole acetic acid/100 g fresh weight.

\section{Statistical analysis:}

The layout of the experiment was completely randomized design. Analysis was carried out using MSTAT-C statistical software (1985) and the means were compared by Duncan's Multiple Rang Test at $\mathrm{p} \leq 0.05 \%$ as described by Waller and Duncan (1969) to verify differences among means of various treatment.

\section{Second experiment:}

\section{Isolation, purification and identification of the microorganisms:}

The plant samples were thoroughly washed with tap water, cut into small pieces and surface sterilized with sodium hypochlorite (3\%) for 3 minutes, washed several times with sterilized water and dried between sterilized filter paper. The sterilized pieces were aseptically transferred to Petri dishes of PDA medium or nutrient agar medium and incubated at $25^{\circ} \mathrm{C}$ for 7 days.

The growing fungi or bacteria were purified using single, hyphal tip techniques or dilution method for bacteria (Dhingra and Sinclair, 1995) and identified according to Booth (1971); Domasch et al. (1980); PlaatsNiterink and Van Der (1981).

The identification was kindly confirmed by Mycol. Res. and Survey Dep., PI. Pathol. Res. Inst. ARC, Giza, Egypt.

\section{Effect of the tested treatments on the isolated microorganisms under lab conditions:}

The treatments at two concentrations were tested to study their inhibitory effect on growth of the isolated microorganisms. Tested treatments were added to conical flasks containing sterilized PDA medium to obtain the proposed concentration, then rotated gently and dispensed in sterilized petri plates $(10 \mathrm{~cm}$ diameter). Plates were individually inoculated at the center with equal disks (5 mm diameter) of 7 days old culture or streak bacteria spores. Five plates were used as replicates for each particular treatment. Inoculated plates were incubated at $27{ }^{\circ} \mathrm{C}$. The average growth of microorganisms tested was calculated after 10 days of incubation.

\section{RESULTS AND DISCUSSION}

\section{Longevity (days to wilting):}

Our results showed that the various antiseptic preservative solutions were effective in extending vase life period of 
Limonium sinuatum cut inflorescences in compared to the control, as documented in Table (1). The significantly highest value was obtained with STS at $500 \mathrm{mg} / \mathrm{l}$ for $1 / 2 \mathrm{~h}$ followed by 8-hydroxyqunoline sulphate $(200 \mathrm{mg} / \mathrm{l})+$ sucrose $(20 \mathrm{~g} / \mathrm{l})$ which recorded 31.3 and 33.9 days in the first and second seasons, respectively. The treatments of $\mathrm{AgNO}_{3}$ at $500 \mathrm{mg} / \mathrm{l}$ for $1 / 2 \mathrm{~h}$ and $\mathrm{AgNO}_{3} 1$ $\mathrm{g} / \mathrm{l}$ for $1 / 2 \mathrm{~h}$ followed by 8-hydroxyqunoline sulphate $(200 \mathrm{mg} / \mathrm{l})+$ sucrose $(20 \mathrm{~g} / \mathrm{l})$ were found to induce a negative effect on vase life of the cut inflorescences. The vase life decreased to 21.7, and 22.5 days in response to daminozide at $25 \mathrm{mg} / \mathrm{l}$ for $24 \mathrm{~h}$ in the first and second seasons, respectively. However the treatment of sodium benzoate at $500 \mathrm{mg} / \mathrm{l}$ for $24 \mathrm{~h}$ recorded the lowest values (20.0 and 22.1 days in both seasons respectively.

Concerning the effect of pulsing solutions treatments on longevity, data presented in Table (1) showed that all treatment gave significantly higher values of vase life in the two seasons than control treatment. These results are in agreement with those of Gul and Inayatullah (2013). They found that pulse treatment of spikes of Narcissus pseudonarcissus flowers with STS ( $0.5 \mathrm{mM}, 1 \mathrm{~h})$ increased solution uptake and STS was the most effective pretreatment solution, significantly extending the vase life and inhibiting microbial growth in the vase (Suong et al., 2017). Bakhsh et al. (1999) found that vase life of tuberose cut flowers increased by pulsing solution containing 200 ppm silver nitrate $\left(\mathrm{AgNO}_{3}\right)$ and $4 \mathrm{mM}$ silver thiosulfate (STS). Arshad et al. (2010) reported that STS applied significantly extended vase life of cut lisianthus flowers as mentioned by Gul and Inayatullah (2013) on Narcissus pseudonarcissus at pulse treatment of spikes STS (0.5 mM, $1 \mathrm{~h})$. Mohy Eldeen (2012) found that significant improvement in vase life of rose cut flowers occurred when pulsed in $30 \mathrm{ppm}\left(\mathrm{AgNO}_{3}\right)$. Pulsing with $\left(\mathrm{AgNO}_{3}\right)$ strikingly enhanced vase life and solution uptake in rose cut flowers. Silver ions present in STS have been found effective ethylene blockers. STS has been shown to inhibit the increase in climacteric respiration and ethylene production of flowers (Finger et al., 2004).

\section{Water uptake:}

The importance of enhancing water uptake as a method for prolonging the vas life of Limonium sinuatum cv. Girlie Wings cut flowers has long been recognized and there are substantial studies of the factors affecting water relations of various species of cut flowers. Regarding the pulsing solutions, solutions of STS at $500 \mathrm{mg} / \mathrm{l}$ for $1 / 2 \mathrm{~h}$ and $\mathrm{AgNO}_{3} 500 \mathrm{mg} / \mathrm{l}$ for $1 / 2 \mathrm{~h}$ had the best impact (133.5, 121.1 and 141.9, 135.4 $\mathrm{g} /$ inflorescence/day, in the two seasons, respectively) on increasing value of water uptake by Limonium cut flowers, contrary with the impact of daminozide $50 \mathrm{mg} / \mathrm{l}$ for $24 \mathrm{~h}$ (69.4 and $73.2 \mathrm{~g}$ /inflorescence/day in both seasons, respectively). Water uptake as shown in Table (1) indicated that all preservative treatments improved water uptake for both seasons in comparison with control.

These findings are in accordance with those attained by Mohammadi and Mosirat (2011) and Al-Humaid et al. (2004) who found that STS reduces bacterial count in the basal parts of gladiolus and rose stems. On Narcissus pseudonarcissus pulse treatment of spikes STS $(0.5 \mathrm{mM}, 1 \mathrm{~h})$ increased solution uptake (Gul and Inayatullah, 2013). Madhavi (2016) exhibited that pulsing with $\mathrm{AgNO}_{3}$ has given good results in improving water relations of gerbera cut flowers.

\section{Water loss:}

End of vase life of cut flowers is characterized by wilting associated with an imbalance developing between water uptake through xylem conduits in stems and water loss through stomata and other structures on leaves and other organs. To better understand the onset of adverse postharvest water relations, cut flower researchers seek to acquire data on rates of water uptake and water loss. These indices are usually monitored by weighing stems and vases daily or thereabout with a single analytical 
Table 1. Effect of pulsing solution treatments on longevity (days), water uptake and water loss (g/inflorescence/day) of Limonium sinuatum cv. Girlie Wings cut inflorescences during the vase life period in 2016 and 2017 seasons.

\begin{tabular}{|c|c|c|c|c|c|c|}
\hline \multirow[b]{2}{*}{ Pulsing treatments } & \multicolumn{3}{|c|}{$1^{\text {st }}$ Season } & \multicolumn{3}{|c|}{$2^{\text {nd }}$ Season } \\
\hline & Longevity & $\begin{array}{c}\text { Water } \\
\text { uptake }\end{array}$ & $\begin{array}{c}\text { Water } \\
\text { loss }\end{array}$ & Longevity & $\begin{array}{l}\text { Water } \\
\text { uptake }\end{array}$ & $\begin{array}{c}\text { Water } \\
\text { loss }\end{array}$ \\
\hline Distilled water (control) & $16.7 \mathrm{i}$ & $38.9 \mathrm{i}$ & $50.7 \mathrm{~h}$ & $18.1 \mathrm{i}$ & $42.9 \mathrm{j}$ & $52.9 \mathrm{k}$ \\
\hline STS at $500 \mathrm{mg} / \mathrm{l}$ for $1 / 4 \mathrm{~h}$ & $27.4 \mathrm{bc}$ & $120.4 \mathrm{bc}$ & 118.6 bc & $30.3 b$ & $123.4 \mathrm{~cd}$ & $121.2 \mathrm{~d} \mathrm{e}$ \\
\hline STS at $500 \mathrm{mg} / \mathrm{l}$ for $1 / 2 \mathrm{~h}$ & $31.3 \mathrm{a}$ & $133.5 \mathrm{a}$ & 130.9 a & $33.1 \mathrm{a}$ & 141.9 a & 135.8 a \\
\hline $\mathrm{AgNO}_{3} 500 \mathrm{mg} / \mathrm{l}$ for $1 / 4 \mathrm{~h}$ & 25.2 c-e & $112.2 \mathrm{~d}$ & $107.4 \mathrm{~d}$ & 26.0 de & 116.9 e & 116.3e \\
\hline $\mathrm{AgNO}_{3} 500 \mathrm{mg} / \mathrm{l}$ for $1 / 2 \mathrm{~h}$ & $28.3 \mathrm{~b}$ & $121.1 \mathrm{~b}$ & $120.6 \mathrm{~b}$ & $29.5 \mathrm{bc}$ & $135.4 \mathrm{~b}$ & $131.8 \mathrm{ab}$ \\
\hline $\mathrm{AgNO}_{3} 1 \mathrm{~g} / \mathrm{l}$ for $1 / 4 \mathrm{~h}$ & $24.4 \mathrm{df}$ & $114.8 \mathrm{~d}$ & 116.3c & 24.6 e-g & $126.3 \mathrm{c}$ & $125.0 \mathrm{~cd}$ \\
\hline $\mathrm{AgNO}_{3} 1 \mathrm{~g} / \mathrm{l}$ for $1 / 2 \mathrm{~h}$ & $26.8 \mathrm{~b}-\mathrm{d}$ & 115.1cd & 118.0 bc & $27.7 \mathrm{~cd}$ & 120.2 de & $120.8 \mathrm{de}$ \\
\hline Sodium benzoate at $250 \mathrm{mg} / \mathrm{l}$ for $12 \mathrm{~h}$ & 23.6 e-g & $110 . .5 d$ & $121.4 \mathrm{~b}$ & 25.3 ef & $123.6 \mathrm{~cd}$ & $127.9 \mathrm{bc}$ \\
\hline Sodium benzoate at $250 \mathrm{mg} / \mathrm{l}$ for $24 \mathrm{~h}$ & $22.1 \mathrm{f}-\mathrm{h}$ & $80.2 \mathrm{f}$ & 91.8 e & $23.2 \mathrm{gh}$ & $82.9 \mathrm{~g}$ & $89.8 \mathrm{gh}$ \\
\hline Sodium benzoate at $500 \mathrm{mg} / \mathrm{l}$ for $12 \mathrm{~h}$ & $21.5 \mathrm{gh}$ & 74.0gh & $74.9 \mathrm{~g}$ & $22.8 \mathrm{gh}$ & $78.9 \mathrm{gh}$ & $80.7 \mathrm{ij}$ \\
\hline Sodium benzoate at $500 \mathrm{mg} / \mathrm{l}$ for $24 \mathrm{~h}$ & $20.0 \mathrm{~h}$ & $70.2 \mathrm{~h}$ & $75.8 \mathrm{~g}$ & $22.1 \mathrm{~h}$ & $76.0 \mathrm{hi}$ & $79.3 \mathrm{j}$ \\
\hline Daminozide at $25 \mathrm{mg} / \mathrm{l}$ for $12 \mathrm{~h}$ & 23.3 e-g & $93.7 \mathrm{e}$ & $108.5 \mathrm{~d}$ & 25.5 e & $98.4 \mathrm{f}$ & $100 . .5 f$ \\
\hline Daminozide 25 mg/l for $24 \mathrm{~h}$ & $21.7 \mathrm{gh}$ & $71.8 \mathrm{~h}$ & $77.6 \mathrm{~g}$ & $22.5 \mathrm{~h}$ & 75.8 e-i & $91.7 \mathrm{~g}$ \\
\hline Daminozide $50 \mathrm{mg} / \mathrm{l}$ for $12 \mathrm{~h}$ & $22.2 \mathrm{f}-\mathrm{h}$ & $78.3 f g$ & $82.9 \mathrm{f}$ & $23.6 \mathrm{f}-\mathrm{h}$ & $75.8 \mathrm{i}$ & 85.5hi \\
\hline Daminozide $50 \mathrm{mg} / \mathrm{l}$ for $24 \mathrm{~h}$ & $21.9 \mathrm{f}-\mathrm{h}$ & $69.4 \mathrm{~h}$ & $78.6 \mathrm{~g}$ & $23.7 \mathrm{~h}$ & $73.2 \mathrm{i}$ & 81.3ij \\
\hline
\end{tabular}

Means within a column having the same letter/letters are not significantly different according to Duncan's multiple Range Test at 5\% level.

balance. (Lü et al., 2009 and Macnich et al., 2008).

Data presented in Table (1) show that water loss of Limonium sinuatum cv. Girlie Wings cut flowers which were pulsed in STS at $500 \mathrm{mg} / \mathrm{l}$ for $1 / 2 \mathrm{~h}$ increased more than the other treatments in the both seasons. Beside, the control (distilled water) was the lowest value between each treatment in both seasons. However, there were no significant differences between the pulsing in sodium benzoate at $500 \mathrm{mg} / \mathrm{l}$ for $12 \mathrm{~h}$, sodium benzoate at $500 \mathrm{mg} / \mathrm{l}$ for $24 \mathrm{~h}$, daminozide $25 \mathrm{mg} / \mathrm{l}$ for $24 \mathrm{~h}$ and daminozide $50 \mathrm{mg} / \mathrm{l}$ for $24 \mathrm{~h}$ in the first season.

\section{Relative fresh weight $\%$ :}

Data presented in Table (2) clearly indicated that during the vase life (seven days after putting flowers in the holding solution) the most effective pulsing solutions in preserving relative fresh weight of cut flowers were in STS at $250 \mathrm{mg} / \mathrm{l}$ for $1 / 2 \mathrm{~h}$ followed by 8 -HQS (200 mg/l) + sucrose (20 $\mathrm{g} / \mathrm{l})$ with significant differences, compared to the control (Distilled water) in two seasons, as they enhanced the relative fresh weight. These findings agreed with those of Gul and Inayatullah (2013) who revealed that the ion leakage of the petal discs was lowered in the STS pulsed spikes particularly in 8-HQS + scu., suggesting increased membrane permeability: treatment with STS increase fresh and dry weight up to 8 days of the treatment on Narcissus pseudonarcissus. Arshad, et al. 2010 stated that STS treated flowers maintained a higher relative fresh weight (RFW) in cut lisianthus flowers. In reference to the second period (14 days of the presence of flowers in solutions) the heights values recorded resulted by STS at $500 \mathrm{mg} / \mathrm{l}$ for $1 / 2 \mathrm{~h}$ and $\mathrm{AgNO}_{3}$ at $500 \mathrm{mg} / \mathrm{l}$ for $1 / 4 \mathrm{~h}$ and $1 / 2 \mathrm{~h}(109.7,107.4,107.3$ and $110,108.2$, 107.8, respectively) in both 
Table 2. Effect of pulsing solution treatments on relative fresh weight \% of Limonium sinuatum cv. Girlie Wings cut inflorescences in the vase life period during 2016 and 2017 seasons.

\begin{tabular}{|c|c|c|c|c|c|c|}
\hline \multirow[b]{2}{*}{ Pulsing treatments } & \multicolumn{3}{|c|}{$1^{\text {st }}$ Season } & \multicolumn{3}{|c|}{$2^{\text {nd }}$ Season } \\
\hline & $\begin{array}{c}\text { After } 7 \\
\text { day }\end{array}$ & $\begin{array}{c}\text { After } 14 \\
\text { days }\end{array}$ & $\begin{array}{c}\text { After } 21 \\
\text { days }\end{array}$ & $\begin{array}{c}\text { After } 7 \\
\text { days }\end{array}$ & $\begin{array}{c}\text { After } 14 \\
\text { days }\end{array}$ & $\begin{array}{c}\text { After } 21 \\
\text { days }\end{array}$ \\
\hline Distilled water (control) & $65.2 \mathrm{~g}$ & $72.2 \mathrm{~h}$ & ---- & $60.6 \mathrm{i}$ & $71.3 \mathrm{i}$ & ---- \\
\hline STS at $500 \mathrm{mg} / \mathrm{l}$ for $1 / 4 \mathrm{~h}$ & $100.3 b$ & $100.4 \mathrm{~d}$ & $56.1 \mathrm{e}$ & 103.1a & $102.2 \mathrm{c}$ & $57.4 \mathrm{ef}$ \\
\hline STS at $500 \mathrm{mg} / \mathrm{l}$ for $1 / 2 \mathrm{~h}$ & 103.8a & $109.7 \mathrm{a}$ & 72.8a & $105.4 \mathrm{a}$ & 110.0a & 74.3a \\
\hline $\mathrm{AgNO}_{3} 500 \mathrm{mg} / \mathrm{l}$ for $1 / 4 \mathrm{~h}$ & 102.3a & 107.4ab & 55.7ef & $100.3 b$ & 108.2ab & 58.2de \\
\hline $\mathrm{AgNO}_{3} 500 \mathrm{mg} / \mathrm{l}$ for $1 / 2 \mathrm{~h}$ & $100.6 b$ & 107.3ab & $66.9 b$ & 103.0a & 107.8ab & $68.6 \mathrm{~b}$ \\
\hline $\mathrm{AgNO}_{3} 1 \mathrm{~g} / \mathrm{l}$ for $1 / 4 \mathrm{~h}$ & $95.3 c$ & $104.5 b c$ & $59.6 \mathrm{c}$ & $95.9 b$ & $106.1 \mathrm{~b}$ & $59.7 \mathrm{~cd}$ \\
\hline $\mathrm{AgNO}_{3} 1 \mathrm{~g} / \mathrm{l}$ for $1 / 2 \mathrm{~h}$ & $87.8 d$ & $103.9 \mathrm{c}$ & 58.1cd & 90.1c & 105.6bc & $60.0 \mathrm{~cd}$ \\
\hline Sodium benzoate at $250 \mathrm{mg} / \mathrm{l}$ for $12 \mathrm{~h}$ & $60.7 \mathrm{hg}$ & 83.3fg & $59.2 \mathrm{c}$ & $63.8 \mathrm{~h}$ & 87.0e-g & $61.2 \mathrm{c}$ \\
\hline Sodium benzoate at $250 \mathrm{mg} / \mathrm{l}$ for $24 \mathrm{~h}$ & 74.3e & $94.2 \mathrm{e}$ & $53.8 f g$ & $74.7 d$ & $96.1 \mathrm{~d}$ & $55.5 f$ \\
\hline Sodium benzoate at $500 \mathrm{mg} / \mathrm{l}$ for $12 \mathrm{~h}$ & $70.8 \mathrm{f}$ & $84.4 \mathrm{f}$ & $50.5 \mathrm{hi}$ & 72.4de & 87.9ef & $52.6 \mathrm{~g}$ \\
\hline Sodium benzoate at $500 \mathrm{mg} / \mathrm{l}$ for $24 \mathrm{~h}$ & $56.6 \mathrm{j}$ & 83.1fg & $46.7 \mathrm{k}$ & $57.8 \mathrm{j}$ & 86.4e-h & $26.2 \mathrm{i}$ \\
\hline Daminozide at $25 \mathrm{mg} / \mathrm{l}$ for $12 \mathrm{~h}$ & $68.3 \mathrm{f}$ & 83.8fg & $47.4 \mathrm{k}$ & 69.6ef & 84.0gh & $50.2 \mathrm{hi}$ \\
\hline Daminozide $25 \mathrm{mg} / \mathrm{l}$ for $24 \mathrm{~h}$ & $65.3 g$ & $80.8 \mathrm{~g}$ & $51.8 \mathrm{gh}$ & $67.5 f g$ & $83.3 \mathrm{~h}$ & $52.8 \mathrm{~g}$ \\
\hline Daminozide 50 mg/l for $12 \mathrm{~h}$ & $57.9 \mathrm{ij}$ & $83.5 f g$ & $49 \mathrm{ij}$ & $66.7 \mathrm{~g}$ & 84.8f-h & 51.1gh \\
\hline Daminozide $50 \mathrm{mg} / \mathrm{l}$ for $24 \mathrm{~h}$ & $56.3 \mathrm{j}$ & $84.6 f$ & $47.5 \mathrm{k}$ & $58.1 \mathrm{j}$ & $83.5 \mathrm{~h}$ & 50.3hi \\
\hline
\end{tabular}

Means within a column having the same letter/letters are not significantly different according to Duncan's multiple Range Test at 5\% level.

seasons. Effect of pulsing with $\mathrm{AgNO}_{3}$ and STS on cut rose, showed the highest gain in fresh weight (Singh and Bhattacharjee, 2000 and Suong et al., 2017).

\section{Floret opening percentage:}

Data presented in Table (3) significantly indicated that all pulsing solutions and holding solution (sucrose 2\% + 8-hydroxyquinoline sulphate $200 \mathrm{mg} / \mathrm{l}$ ) mostly increased floret opening percentage. In this concern, pulsing in STS at $500 \mathrm{mg} / \mathrm{l}$ for $1 / 4 \mathrm{~h}$ effect on floret opening percentage was not significantly different from pulsing in solution of STS at $500 \mathrm{mg} / \mathrm{l}$ for $1 / 2 \mathrm{~h}$ in the two seasons. Regarding the solutions effect of pulsing, $\mathrm{AgNO}_{3}$ at $500 \mathrm{mg} / \mathrm{l}$ for $1 / 2 \mathrm{~h}$ and daminozide $25 \mathrm{mg} / \mathrm{l}$ for $24 \mathrm{~h}$ significantly increased floret opening percentage (87.5, 87.3 and 92.8, 88.4, respectively in both seasons). On the contrary, the shortest percentage of floret opening was observed with the sodium benzoate at $500 \mathrm{mg} / \mathrm{l}$ for 12 h by 31.4 and $35.6 \%$, respectively in both seasons. This results are in harmony with those of Saichol et al. (1995) who stated that $\mathrm{AgNO}_{3}$ was more effective in controlling microbial growth and in maximizing bud opening of Dendrobium 'Pompadour'.

\section{Dry weight:}

Data exhibited in Table (3) cleared that cut Limonium inflorescences pulsed in the solution of STS at $500 \mathrm{mg} / \mathrm{l}$ for $1 / 2 \mathrm{~h}, \mathrm{STS}$ at $500 \mathrm{mg} / \mathrm{l}$ for $1 / 4 \mathrm{~h}, \mathrm{AgNO}_{3} 500 \mathrm{mg} / \mathrm{l}$ for $1 / 2$ $\mathrm{h}$ and daminozide $25 \mathrm{mg} / \mathrm{l}$ for $24 \mathrm{~h}$ significantly increased dry weight compared to those pulsed in the solution of sodium benzoate at $250 \mathrm{mg} / \mathrm{l}$ for $24 \mathrm{~h}$ in the two seasons. Cut inflorescences held in distilled water (control) gave the lowest dry weight. This may be to that the function of sucrose in offering the desired energy for the survival of flower and affects the structure of the 
Table 3. Effect of pulsing solution treatments on floret opening $\%$ and dry weight percentage \%, of Limonium sinuatum cv. Girlie Wings cut inflorescences during the vase life period in 2016 and 2017 seasons.

\begin{tabular}{|c|c|c|c|c|}
\hline \multirow[b]{2}{*}{ Pulsing treatments } & \multicolumn{2}{|c|}{$1^{\text {st }}$ Season } & \multicolumn{2}{|c|}{$2^{\text {nd }}$ Season } \\
\hline & $\begin{array}{c}\text { Floret opening } \\
\%\end{array}$ & D.W. \% & $\begin{array}{c}\text { Floret opening } \\
\%\end{array}$ & D.W. \% \\
\hline Distilled water (control) & $25.4 \mathrm{k}$ & $56.6 \mathrm{~g}$ & $30.2 \mathrm{i}$ & $54.2 \mathrm{~h}$ \\
\hline STS at $500 \mathrm{mg} / \mathrm{l}$ for $1 / 4 \mathrm{~h}$ & $90.3 \mathrm{ab}$ & 80.3 bc & 94.5 a & $80.5 \mathrm{bc}$ \\
\hline STS at $500 \mathrm{mg} / \mathrm{l}$ for $1 / 2 \mathrm{~h}$ & 92.6 a & $84.1 \mathrm{a}$ & 95.6 a & 85.6 a \\
\hline $\mathrm{AgNO}_{3} 500 \mathrm{mg} / \mathrm{l}$ for $1 / 4 \mathrm{~h}$ & $85.2 \mathrm{c}$ & 80.1 bc & 89.3 bc & $80.7 \mathrm{bc}$ \\
\hline $\mathrm{AgNO}_{3} 500 \mathrm{mg} / \mathrm{l}$ for $1 / 2 \mathrm{~h}$ & 87.5 bc & $83.0 \mathrm{ab}$ & $92.8 \mathrm{ab}$ & $82.0 \mathrm{ab}$ \\
\hline $\mathrm{AgNO}_{3} 1 \mathrm{~g} / \mathrm{l}$ for $1 / 4 \mathrm{~h}$ & $80.3 \mathrm{~d}$ & $61.8 \mathrm{f}$ & $86.1 \mathrm{c}$ & $56.7 \mathrm{gh}$ \\
\hline $\mathrm{AgNO}_{3} 1 \mathrm{~g} / \mathrm{l}$ for $1 / 2 \mathrm{~h}$ & $57.0 \mathrm{f}$ & $71.3 \mathrm{~d}$ & 61.8 e & $71.0 \mathrm{~d}$ \\
\hline Sodium benzoate at $250 \mathrm{mg} / \mathrm{l}$ for $12 \mathrm{~h}$ & $35.4 \mathrm{i}$ & $62.0 \mathrm{f}$ & $38.9 \mathrm{gh}$ & $59.3 \mathrm{fg}$ \\
\hline Sodium benzoate at $250 \mathrm{mg} / \mathrm{l}$ for $24 \mathrm{~h}$ & $28.3 \mathrm{jk}$ & $55.5 \mathrm{gh}$ & 34.4 hi & $63.6 \mathrm{e}$ \\
\hline Sodium benzoate at $500 \mathrm{mg} / \mathrm{l}$ for $12 \mathrm{~h}$ & $31.4 \mathrm{i}$ & 68.0 de & $35.6 \mathrm{~h}$ & $70.5 \mathrm{~d}$ \\
\hline Sodium benzoate at $500 \mathrm{mg} / \mathrm{l}$ for $24 \mathrm{~h}$ & 76.7 e & 66.4 e & $80.7 \mathrm{~d}$ & 65.5 e \\
\hline Daminozide at $25 \mathrm{mg} / \mathrm{l}$ for $12 \mathrm{~h}$ & $48.2 \mathrm{~g}$ & $79.6 \mathrm{c}$ & $53.4 \mathrm{f}$ & $78.6 \mathrm{c}$ \\
\hline Daminozide $25 \mathrm{mg} / \mathrm{l}$ for $24 \mathrm{~h}$ & $87.3 \mathrm{bc}$ & $80.2 \mathrm{~b} \mathrm{c}$ & 88.4 bc & $82.0 \mathrm{ab}$ \\
\hline Daminozide $50 \mathrm{mg} / \mathrm{l}$ for $12 \mathrm{~h}$ & $38.8 \mathrm{~g}$ & $65.6 \mathrm{e}$ & $40.7 \mathrm{~g}$ & $62.4 \mathrm{ef}$ \\
\hline Daminozide $50 \mathrm{mg} / \mathrm{l}$ for $24 \mathrm{~h}$ & $59.3 \mathrm{e}$ & $78.5 \mathrm{c}$ & $60.5 \mathrm{e}$ & 77.9 c \\
\hline
\end{tabular}

Means within a column having the same letter/letters are not significantly different according to Duncan's multiple Range Test at 5\% level.

flower cell walls and delays getting older tissues, and increased the dry weight and water retention. Compounds extending the vase life of cut flower on the prevention of dry weight loss with the aid of preventing the degradation of carbohydrates (Dashtbany and Hashemabadi, 2015). Gul and Inayatullah (2013) revealed that pulse treatment of spikes with STS $(0.5 \mathrm{mM}, 1 \mathrm{~h})$ increased dry mass of Narcissus pseudonarcissus flowers.

\section{Chemical composition:}

Using STS as a pulse preservation solution had a positive effect on Limonium cut inflorescences as presented in Table (4) which cleared that treating cut inflorescences with STS at $500 \mathrm{mg} / \mathrm{l}$ for $1 / 4 \mathrm{~h}$ and STS at $500 \mathrm{mg} / \mathrm{l}$ for $1 / 2 \mathrm{~h}$ enhanced chlorophyll a, b and carotenoid contents compared to the control, in both seasons. On the other hand, daminozide pulsing solution retarded the degradation of chlorophyll a and chlorophyll b, which were at least values. It can be concluded that Limonium sinuatum cut inflorescences treated by $\mathrm{AgNO}_{3}$ gave significantly the highest means of the leaves content of chlorophyll a and chlorophyll b as compared to the control. This might be due to inhibiting ethylene action. Suong et al. (2017) revealed that STS was the most effective on increasing chlorophyll content in the leaves of the cut rose flowers.

\section{Anthocyanin content (mg/100 g f.w.):}

Data presented in Table (5) showed that in both seasons, the significantly highest contents of anthocyanin were recorded with petals of flowers pulsed with STS at 500 $\mathrm{mg} / \mathrm{l}$ for $1 / 2 \mathrm{~h}$ compared to the other solutions. However, the best results were gained by STS at $500 \mathrm{mg} / \mathrm{l}$ for $1 / 4 \mathrm{~h}$ and sodium benzoate at $250 \mathrm{mg} / \mathrm{l}$ for $12 \mathrm{~h}$ pulsing solution, which gave the highest 
Table 4. Effect of pulsing solution treatments on chlorophyll a, b and carotenoids (mg/100 g f.w.) of Limonium sinuatum cv. Girlie Wings cut inflorescences during the vase life period in 2016 and 2017 seasons.

\begin{tabular}{|c|c|c|c|c|c|c|}
\hline \multirow{2}{*}{ Pulsing treatments } & \multicolumn{3}{|c|}{$1^{\text {st }}$ Season } & \multicolumn{3}{|c|}{$2^{\text {nd }}$ Season } \\
\hline & Chl. a & Chl. b & Caro. & Chl. a & Chl. b & Caro. \\
\hline Distilled water (control) & $0.39 \mathrm{j}$ & $0.22 \mathrm{~g}$ & $0.27 \mathrm{e}$ & $0.35 \mathrm{j}$ & 0.28 ef & 0.35 c-e \\
\hline STS at $500 \mathrm{mg} / \mathrm{l}$ for $1 / 4 \mathrm{~h}$ & 0.93 a & $0.46 \mathrm{a}$ & $0.43 \mathrm{ab}$ & $1.03 \mathrm{~b}$ & $0.47 \mathrm{a}$ & $0.44 \mathrm{a}$ \\
\hline STS at $500 \mathrm{mg} / \mathrm{l}$ for $1 / 2 \mathrm{~h}$ & $0.98 \mathrm{a}$ & $0.50 \mathrm{a}$ & $0.45 \mathrm{a}$ & $1.12 \mathrm{a}$ & $0.49 \mathrm{a}$ & $0.45 \mathrm{a}$ \\
\hline $\mathrm{AgNO}_{3} 500 \mathrm{mg} / \mathrm{l}$ for $1 / 4 \mathrm{~h}$ & $0.82 \mathrm{~b}$ & $0.37 \mathrm{~b}$ & $0.43 \mathrm{ab}$ & $0.85 \mathrm{c}$ & $0.36 \mathrm{bc}$ & $0.37 \mathrm{~b}-\mathrm{c}$ \\
\hline $\mathrm{AgNO}_{3} 500 \mathrm{mg} / \mathrm{l}$ for $1 / 2 \mathrm{~h}$ & $0.80 \mathrm{bc}$ & $0.34 \mathrm{~b}-\mathrm{d}$ & 0.32 de & $0.83 \mathrm{c}$ & $0.39 \mathrm{~b}$ & $0.28 \mathrm{f}$ \\
\hline $\mathrm{AgNO}_{3} 1 \mathrm{~g} / \mathrm{l}$ for $1 / 4 \mathrm{~h}$ & 0.75 c & $0.35 \mathrm{bc}$ & 0.29 e & $0.77 \mathrm{~d}$ & $0.36 \mathrm{bc}$ & 0.30 ef \\
\hline $\mathrm{AgNO}_{3} 1 \mathrm{~g} / \mathrm{l}$ for $1 / 2 \mathrm{~h}$ & $0.79 \mathrm{bc}$ & $0.34 \mathrm{~b}-\mathrm{d}$ & 0.30 de & $0.80 \mathrm{~cd}$ & $0.35 \mathrm{~b}-\mathrm{d}$ & $0.32 \mathrm{~d}-\mathrm{f}$ \\
\hline Sodium benzoate at $250 \mathrm{mg} / \mathrm{l}$ for $12 \mathrm{~h}$ & $0.63 \mathrm{de}$ & $0.29 \mathrm{~d}-\mathrm{f}$ & $0.40 \mathrm{a}-\mathrm{c}$ & $0.67 \mathrm{e}$ & $0.32 \mathrm{c}-\mathrm{d}$ & $0.42 \mathrm{ab}$ \\
\hline Sodium benzoate at $250 \mathrm{mg} / \mathrm{l}$ for $24 \mathrm{~h}$ & 0.65 de & $0.28 \mathrm{ef}$ & $35.0 \mathrm{~cd}$ & 0.68 e & $0.30 \mathrm{~d}-\mathrm{f}$ & $0.32 \mathrm{~d}-\mathrm{f}$ \\
\hline Sodium benzoate at $500 \mathrm{mg} / \mathrm{l}$ for $12 \mathrm{~h}$ & 0.60 ef & $0.26 \mathrm{fg}$ & $0.40 \mathrm{a}-\mathrm{c}$ & 0.65 ef & 0.29 ef & $0.43 \mathrm{a}$ \\
\hline Sodium benzoate at $500 \mathrm{mg} / \mathrm{l}$ for $24 \mathrm{~h}$ & $0.67 \mathrm{~d}$ & $0.30 \mathrm{c}-\mathrm{f}$ & $0.38 \mathrm{bc}$ & $0.69 \mathrm{e}$ & 0.33 c-e & $0.40 \mathrm{a}-\mathrm{c}$ \\
\hline Daminozide at $25 \mathrm{mg} / \mathrm{l}$ for $12 \mathrm{~h}$ & $0.55 \mathrm{fg}$ & $0.25 \mathrm{fg}$ & 0.30 de & $0.60 \mathrm{fg}$ & $0.26 \mathrm{f}$ & 0.31 ef \\
\hline Daminozide $25 \mathrm{mg} / \mathrm{l}$ for $24 \mathrm{~h}$ & $0.50 \mathrm{gh}$ & $0.29 \mathrm{~d}-\mathrm{f}$ & $0.39 \mathrm{bc}$ & $0.55 \mathrm{~g}$ & $0.30 \mathrm{~d}-\mathrm{f}$ & $0.44 \mathrm{a}$ \\
\hline Daminozide $50 \mathrm{mg} / \mathrm{l}$ for $12 \mathrm{~h}$ & $0.40 \mathrm{ij}$ & $0.33 \mathrm{~b}-\mathrm{e}$ & $0.40 \mathrm{a}-\mathrm{c}$ & $0.43 \mathrm{i}$ & $0.37 \mathrm{bc}$ & $0.42 \mathrm{ab}$ \\
\hline Daminozide $50 \mathrm{mg} / \mathrm{l}$ for $24 \mathrm{~h}$ & $0.45 \mathrm{hi}$ & $0.35 \mathrm{bc}$ & $0.38 \mathrm{bc}$ & $0.49 \mathrm{~h}$ & $0.40 \mathrm{~b}$ & $0.43 \mathrm{a}$ \\
\hline
\end{tabular}

Means within a column having the same letter/letters are not significantly different according to Duncan's multiple Range Test at 5\% level.

Table 5. Effect of pulsing solution treatments on anthocyanine (mg/100 g f.w.) and total carbohydrate \% of Limonium sinuatum cv. Girlie Wings cut flowers during the vase life period in 2016 and 2017 seasons.

\begin{tabular}{|c|c|c|c|c|}
\hline \multirow{2}{*}{ Pulsing treatments } & \multicolumn{2}{|c|}{$1^{\text {st }}$ Season } & \multicolumn{2}{|c|}{$2^{\text {nd }}$ Season } \\
\hline & Anthocyanine & Carbohydrate & Anthocyanine & Carbohydrate \\
\hline Distilled water (control) & $0.50 \mathrm{~d} \mathrm{e}$ & $23.8 \mathrm{j}$ & $0.52 \mathrm{ef}$ & $24.1 \mathrm{i}$ \\
\hline STS at $500 \mathrm{mg} / \mathrm{l}$ for $1 / 4 \mathrm{~h}$ & $1.05 \mathrm{ab}$ & $60.2 \mathrm{~b}$ & $1.14 \mathrm{~b}$ & $61.4 \mathrm{a}$ \\
\hline STS at $500 \mathrm{mg} / \mathrm{l}$ for $1 / 2 \mathrm{~h}$ & $1.26 \mathrm{a}$ & $65.1 \mathrm{a}$ & $1.29 \mathrm{a}$ & $63.8 \mathrm{a}$ \\
\hline $\mathrm{AgNO}_{3} 500 \mathrm{mg} / \mathrm{l}$ for $1 / 4 \mathrm{~h}$ & $0.57 \mathrm{~cd}$ & $49.5 \mathrm{c}$ & $0.62 \mathrm{~d}$ & $50.3 \mathrm{~b}$ \\
\hline $\mathrm{AgNO}_{3} 500 \mathrm{mg} / \mathrm{l}$ for $1 / 2 \mathrm{~h}$ & $0.39 \mathrm{~d}-\mathrm{f}$ & $45.3 \mathrm{e}$ & $0.43 \mathrm{f}$ & $47.5 \mathrm{~cd}$ \\
\hline $\mathrm{AgNO}_{3} 1 \mathrm{~g} / \mathrm{l}$ for $1 / 4 \mathrm{~h}$ & $0.13 \mathrm{~g}$ & $47.8 \mathrm{~cd}$ & $0.15 \mathrm{~h}$ & $49.6 \mathrm{bc}$ \\
\hline $\mathrm{AgNO}_{3} 1 \mathrm{~g} / \mathrm{l}$ for $1 / 2 \mathrm{~h}$ & 0.29 e-g & 46.3 de & $0.29 \mathrm{~g}$ & $49.9 \mathrm{~d}$ \\
\hline Sodium benzoate at $250 \mathrm{mg} / \mathrm{l}$ for $12 \mathrm{~h}$ & $1.02 \mathrm{ab}$ & $54.3 \mathrm{c}$ & $1.05 \mathrm{~b}$ & $55.2 \mathrm{c}$ \\
\hline Sodium benzoate at $250 \mathrm{mg} / \mathrm{l}$ for $24 \mathrm{~h}$ & $0.81 \mathrm{bc}$ & $36.2 \mathrm{fg}$ & $0.84 \mathrm{c}$ & 37.5 ef \\
\hline Sodium benzoate at $500 \mathrm{mg} / \mathrm{l}$ for $12 \mathrm{~h}$ & $0.15 \mathrm{fg}$ & $30.5 \mathrm{~h}$ & $0.15 \mathrm{~h}$ & $31.1 \mathrm{~h}$ \\
\hline Sodium benzoate at $500 \mathrm{mg} / \mathrm{l}$ for $24 \mathrm{~h}$ & $0.14 \mathrm{fg}$ & $31.7 \mathrm{~h}$ & $0.18 \mathrm{~h}$ & $33.9 \mathrm{~g}$ \\
\hline Daminozide at $25 \mathrm{mg} / \mathrm{l}$ for $12 \mathrm{~h}$ & $0.61 \mathrm{~cd}$ & $25.5 \mathrm{ij}$ & 0.61 de & $26.3 \mathrm{i}$ \\
\hline Daminozide $25 \mathrm{mg} / \mathrm{l}$ for $24 \mathrm{~h}$ & $0.60 \mathrm{~cd}$ & $38.4 \mathrm{f}$ & $0.63 \mathrm{~d}$ & $29.5 \mathrm{e}$ \\
\hline Daminozide $50 \mathrm{mg} / \mathrm{l}$ for $12 \mathrm{~h}$ & $0.12 \mathrm{~g}$ & $37.8 \mathrm{f}$ & $0.15 \mathrm{~h}$ & $38.6 \mathrm{e}$ \\
\hline Daminozide $50 \mathrm{mg} / \mathrm{l}$ for $24 \mathrm{~h}$ & $0.40 \mathrm{~d}-\mathrm{f}$ & $27.5 \mathrm{i}$ & $0.14 \mathrm{~h}$ & $29.4 \mathrm{~h}$ \\
\hline
\end{tabular}

Means within a column having the same letter/letters are not significantly different according to Duncan's multiple Range Test at 5\% level. 


\section{E.A. Khella et al.}

records in the two seasons. Khalid (2012) reported that concentrations of anthocyanin in the petals were higher in with STS pulsing treatments in cut sweet pea flowers.

\section{Total carbohydrate percentage \%:}

According to results shown in Table (5), pulsing Limonium sinuatum cv. Girlie Wings cut flowers with STS at $500 \mathrm{mg} / \mathrm{l}$ for $1 / 2 \mathrm{~h}$ and STS at $500 \mathrm{mg} / \mathrm{l}$ for $1 / 4 \mathrm{~h}$ then holding in solution containing 8-hydroxyqunoline sulphate $(200 \mathrm{mg} / \mathrm{l})+$ sucrose $(20 \mathrm{~g} / \mathrm{l})$ produced the maximum amount of carbohydrates\% compared to the control during the two seasons. The percentage of total carbohydrates decreased in Limonium flowers pulsed in daminozide solution at 25 $\mathrm{mg} / \mathrm{l}$ for $12 \mathrm{~h}$ then holding in solution containing 8-hydroxyqunoline sulphate (200 $\mathrm{mg} / \mathrm{l})+$ sucrose (20 g/l) (25.5 and $26.3 \%$ in both seasons, respectively) and pulsing in daminozide solution $50 \mathrm{mg} / \mathrm{l}$ for $24 \mathrm{~h}$ (27.5 and $29.4 \%$ in both seasons, respectively) compared to all treatments. Results of the present study are in line with the findings attained by Suong et al. (2017) who revealed that STS inhibits microbial growth in the vase. STS also maintained the high soluble sucrose contents in the leaves of cut rose flowers. This was also stated by Khalid (2012) on cut sweet pea flowers. He found that anthocyanin concentrations increased by treatments with STS followed by sucrose during the postharvest life.

\section{Total phenols and total indoles:}

As shown in Table (6) it can be concluded that the highest amount of total phenols and total indoles (mg/100 g f.w.) were found in flowers treated with STS at $500 \mathrm{mg} / \mathrm{l}$ for $1 / 2 \mathrm{~h}$ compared to the other treatments, in both seasons. Using AgNO3 at $500 \mathrm{mg} / \mathrm{l}$ for $1 / 4 \mathrm{~h}$ and $\mathrm{AgNO}_{3}$ at $500 \mathrm{mg} / \mathrm{l}$ for $1 / 2 \mathrm{~h}$ gave a high value, and there was no significant differences among them in total phenol, in two seasons. Higher phenolic content in spikes pulsed with STS of extended the vase life, particularly in 8-HQS + suc vase solution. The higher content of total phenols has been shown to be associated with longer vase life in cut rose petals Hemerocallis (Mwangi et al., 2003 and Gulzar et al., 2005).

\section{Second experiment:}

\section{Isolation, purification and identification of the microorganisms:}

Data presented in Table (7) illustrated the frequency of the isolated microorganisms from the samples. Mucor sp. (31.30), Aspergillus niger (23.4) and Penecillium sp. (17.5) recorded the highest percentages, while, A. alternate (0.2.3) was the least ones in this respect.

Data presented in Table (8) show that STS was the most effective treatments, whereas it completely inhibited growth of all isolated microoraganisms by $100 \%$ on the other hand, daminozide was the least one in this respect.

\section{Conclusion:}

Regarding the obtained results, it is able to be concluded that pulsing in STS at 500 $\mathrm{mg} / \mathrm{l}$ for $1 / 2 \mathrm{~h}$ followed by transfer to 8hydroxyqunoline sulphate $(200 \mathrm{mg} / \mathrm{l})$ + sucrose $(20 \mathrm{~g} / \mathrm{l})$ prolonged vase life and delayed senescence as compared to other treatments. It preserves the execution of flowers according to various measurements taken as water uptake, relative fresh weight, dry weight percentage of cut flowers, floret opening percentage, pigments content, inhibited growth of all isolated microorganisms and enhancing postharvest evolution of Limonium sinuatum cv. Girlie Wings cut flowers.

\section{REFERENCES}

A.O.A.C. (1990). Official Methods of Analysis. $13^{\text {th }}$ Ed. Association of Official Analytical Chemists, Washington D.C., USA.

A.O.A.C. (1995). Official Methods of Analysis of the Official Analysis Chemist Washington 25. D.C., USA. 
Table 6. Effect of pulsing solution treatments on total phenols and total indoles $(\mathrm{mg} / 100$ g f.w.) of Limonium sinuatum cv. Girlie Wings cut flowers in the vase life period in 2016 and 2017 seasons.

\begin{tabular}{|c|c|c|c|c|}
\hline \multirow{2}{*}{ Pulsing treatments } & \multicolumn{2}{|c|}{$1^{\text {st }}$ Season } & \multicolumn{2}{|c|}{$2^{\text {nd }}$ Season } \\
\hline & Total phenols & Total indoles & Total phenols & Total indoles \\
\hline Distilled water (control) & $0.59 \mathrm{ij}$ & $0.40 \mathrm{~cd}$ & $0.62 \mathrm{gh}$ & $0.42 \mathrm{~g}$ \\
\hline STS at $500 \mathrm{mg} / \mathrm{l}$ for $1 / 4 \mathrm{~h}$ & $3.43 \mathrm{~b}$ & $1.10 \mathrm{~b}$ & $3.60 \mathrm{~b}$ & $1.20 \mathrm{~b}$ \\
\hline $\mathrm{STS}$ at $500 \mathrm{mg} / \mathrm{l}$ for $1 / 2 \mathrm{~h}$ & 3.99 a & $1.50 \mathrm{a}$ & $4.00 \mathrm{a}$ & $1.61 \mathrm{a}$ \\
\hline $\mathrm{AgNO}_{3} 500 \mathrm{mg} / \mathrm{l}$ for $1 / 4 \mathrm{~h}$ & $2.20 \mathrm{~d}$ & $0.41 \mathrm{~cd}$ & $2.40 \mathrm{c}$ & 0.45 ef \\
\hline $\mathrm{AgNO}_{3} 500 \mathrm{mg} / \mathrm{l}$ for $1 / 2 \mathrm{~h}$ & $2.415 \mathrm{c}$ & 0.32 c-e & $2.50 \mathrm{c}$ & $0.36 \mathrm{hf}$ \\
\hline $\mathrm{AgNO}_{3} 1 \mathrm{~g} / \mathrm{l}$ for $1 / 4 \mathrm{~h}$ & 0.76 hi & $0.33 \mathrm{~cd}$ & $0.90 \mathrm{fg}$ & $0.37 \mathrm{~h}$ \\
\hline $\mathrm{AgNO}_{3} 1 \mathrm{~g} / \mathrm{l}$ for $1 / 2 \mathrm{~h}$ & $0.87 \mathrm{~h}$ & 0.30 c-e & $0.950 \mathrm{fg}$ & $0.34 \mathrm{i}$ \\
\hline Sodium benzoate at $250 \mathrm{mg} / \mathrm{l}$ for $12 \mathrm{~h}$ & $1.12 \mathrm{~g}$ & 0.22 de & 1.23 ef & $0.25 \mathrm{j}$ \\
\hline Sodium benzoate at $250 \mathrm{mg} / \mathrm{l}$ for $24 \mathrm{~h}$ & $1.11 \mathrm{~g}$ & $0.50 \mathrm{c}$ & 1.33 ef & $0.53 \mathrm{~d}$ \\
\hline Sodium benzoate at $500 \mathrm{mg} / \mathrm{l}$ for $12 \mathrm{~h}$ & $1.47 \mathrm{f}$ & $0.11 \mathrm{e}$ & 1.60 de & $0.16 \mathrm{k}$ \\
\hline Sodium benzoate at $500 \mathrm{mg} / \mathrm{l}$ for $24 \mathrm{~h}$ & $1.82 \mathrm{e}$ & $0.51 \mathrm{c}$ & $1.90 \mathrm{~d}$ & $0.56 \mathrm{c}$ \\
\hline Daminozide at $25 \mathrm{mg} / \mathrm{l}$ for $12 \mathrm{~h}$ & $1.23 \mathrm{gh}$ & 0.30 c-e & $1.40 \mathrm{e}$ & 0.35 hi \\
\hline Daminozide 25 mg/l for $24 \mathrm{~h}$ & $0.49 \mathrm{~g}$ & $0.43 \mathrm{~cd}$ & $0.50 \mathrm{~h}$ & $0.47 \mathrm{e}$ \\
\hline Daminozide 50 mg/l for 12 h & $2.21 \mathrm{j}$ & 0.25 de & $2.30 \mathrm{c}$ & $0.26 \mathrm{j}$ \\
\hline Daminozide 50 mg/l for $24 \mathrm{~h}$ & $0.68 \mathrm{i}$ & $0.41 \mathrm{~cd}$ & 0.69 gh & $0.44 \mathrm{fg}$ \\
\hline \multicolumn{5}{|c|}{$\begin{array}{l}\text { Means within a column having the same letter/letters are not significantly different according to } \\
\text { Duncan's multiple Range Test at } 5 \% \text { level. }\end{array}$} \\
\hline \multicolumn{5}{|c|}{ Table 7. Occurrence percentages of the fungi isolated from samples. } \\
\hline Fungi & \multicolumn{3}{|c|}{ Frequency (\%) } & \\
\hline Alternaria alternata Nees. (A) & \multicolumn{3}{|c|}{02.3} & \\
\hline Aspergillus niger (B) & \multicolumn{3}{|c|}{23.4} & \\
\hline F. moniliforme J. Scheld. (C) & \multicolumn{3}{|c|}{2.70} & \\
\hline Pythium ultimum Braun (D) & \multicolumn{3}{|c|}{11.2} & \\
\hline Penecillium sp. (E) & \multicolumn{3}{|c|}{17.5} & \\
\hline Bacillus subtilis (F) & \multicolumn{3}{|c|}{10.2} & \\
\hline Mucor sp. (G) & \multicolumn{3}{|c|}{31.3} & \\
\hline
\end{tabular}

Table 8. Effect of the tested treatments on the isolated microorganisms under lab. conditions.

\begin{tabular}{|c|c|c|c|c|c|c|c|c|}
\hline Treatment & Conc. & $\mathbf{A}$ & B & C & $\mathbf{D}$ & $\mathbf{E}$ & $\begin{array}{c}\mathbf{F} \\
\text { Inhibition } \\
\text { zone } \\
\end{array}$ & $\mathbf{G}$ \\
\hline Daminozide & 25 mg/l & 3.2 & 4.1 & 5.2 & 1.0 & 3.6 & 2.4 & 3.7 \\
\hline Daminozide & 50 mg/l & 1.0 & 2.4 & 3.2 & 00 & 1.2 & 9.0 & 1.7 \\
\hline STS & 500 mg/l & 0.0 & 0.0 & 0.0 & 0.0 & 0.0 & 9.0 & 0.0 \\
\hline Sodium benzoate & $250 \mathrm{mg} / \mathrm{l}$ & 0.0 & 1.1 & 2.7 & 3.1 & 1.5 & 5.6 & 2.4 \\
\hline Sodium benzoate & 500 mg/l & 0.0 & 0.5 & 2.2 & 1.3 & 1.1 & 3.1 & 1.5 \\
\hline Ag NO3 & 500 mg/l & 0.0 & 0.0 & 0.0 & 0.9 & 0.0 & 6.5 & 0.8 \\
\hline Ag NO3 & $1 \mathrm{~g} / \mathrm{l}$ & 0.0 & 0.0 & 1.3 & 0.7 & 0.0 & 6.5 & 0.7 \\
\hline
\end{tabular}

Alternaria alternate Nees.(A), Aspergillus niger (B), F. moniliforme J. Scheld. (C), Pythium ultimum, Braun (D), Penecillium sp. (E), Bacillus subtilis (F), Mucor sp. (G). 


\section{E.A. Khella et al.}

Abdul-Wasea, A.A. (2012). Effects of some preservative solutions on vase life and keeping quality of snapdragon (Antirrhinum majus L.) cut flowers. Journal of the Saudi Society of Agric. Sci., 11(1):29-35.

Al-Humaid, A. (2004). Silver thiosulfate prolongs vas live and improves quality of cut gladiolus and rose flowers. J. Food Agric. and Environment, 2(1):296-300.

Amit, K.; Karhanab, P.K. and Pandeyc, K.K. (2013). Application of the preservatives on quality gladiolus (Gladiolus grandiflorus) cut spike. International Journal of Plant, Animal and Environmental Sciences, 3(3):1-4.

Arshad, M.; Esmaeil, C. and Younes, P. (2010). Effects of silver thiosulfate treatment on postharvest life of cut lisianthus flowers. Acta Hort., 877:17851790 •

Asrar, A.W.A. (2012). Effects of some preservative solutions on vase life and keeping quality of snapdragon (Antirrhinum majus L.) cut flowers. J. Saudi Soc. Agric. Sci., 11:29-35.

Bakhsh, A.; Muhammad, A.K., Ayyub, C.M.; Mubarak, A. and Afza, M. (1999). Effect of various chemicals on vase life and quality of cut tuberose flowers. Pakistan Journal of Biological Sciences, 2(3):914-916.

Bang, C.S.; Song, C.Y.; Lee, J.S.; Huh, K.Y. and Song, J. (1999). Effect of pretreatment and storage conditions on quality and vase life of cut 'Red Sandra' rose. Korean J. Hort. Sci. Techno, 17(6): 762-764.

Beura, S.; Ranvir, S.; Beura, S. and Sing, R. (2001). Effect of sucrose pulsing before storage on postharvest life of gladiolus. J. Ornamen. Hort. New Series, 4(2):91-94

Booth. C. (1971). The Genus Fusarium. Cormmonw. Mycol. Inst., Kew., Surey. England.
Darras, A.L. and Pompodakis, N. (2010). Evaluation and improvement of postharvest performance of cut Viburnum tinus inflorescence. Sci. Hort., 124:376380. DOI: 10.1016/j.scienta.2010.01.018.

Dashtbany, S. and Hashemabadi, D. (2015). Study on interaction effects of mechanical and geranium essential oil treatments on vase life of cut chrysanthemum (Dendranthema grandiflorum L.). J. Orn. Pla., 5(2):97103.

Davood, H., Mahfam, H.I.; Behzad, K. and Mohammad, Z. (2012). Effect of sodium benzoate on longevity and ethylene production in cut rose (Rosa hybrida L. cv. Avalanche) flower. Euro. J. Exp. Bio., 2(6):2485-2488.

Dhingra, O.D. and Sinclair, J.B. (1995). Basic Plant Pathology Methods. Lewis Publ. USA, 434 pp.

Dineshbabu, M.; Jawaharlal, M. and Vijayakumar, M. (2002). Influence of holding solutions on the postharvest life of Dendrobium hybrid Sonia. South Indian Hort., 50(4-6):451-457.

Domaseh, K.H.; Gams, W. and Anderson, T.H. (1980). Compendium of Soil Fungi. Vol. 1\& 2, Academic Press, London.

Dung, C.D.; Seaton, K. and Singh, Z. (2017). Influence of type and concentration of sugars, supplemented with 8hydroxyquinoline sulphate, on the vase life of axflower. Flora Hort., 29(1):39-49.

Elgimabi, M.E. (2011). Vase life extension of rose cut flower (Rosa hybrida) as influenced by silver nitrate and sucrose pulsing. Amer. J. of Agric. and Biolog. Sci., 6(1):128-133.

Elgimabi, M.N. and Ahmed, O.K. (2009). Effects of bactericides and sucrose pulsing on vase life of rose cut flowers (Rosa hybirda). Botany Research International, 2(3):164-168. 
Finger, F.L.; Carneiro, T.F. and Barbosa, J.G. (2004). Post-harvest senescence of inflorescences of esporinha (Consolida ajacis). Brasilia, 39:533-537.

Fuleki, T. and Francis, F.J. (1968). Standards for Guantative Analysis of Anthocyanins. Amer. Hort. Soc., p: 287-294.

Gul, F. and Inayatullah, T. (2013). Efficacy of STS pulsing and floral preservative solutions on senescence and post harvest performance of Narcissus pseudonarcissus cv. Emperor. Trends in Horti. Res., 3(1):14-26.

Gulzar, S.; Tahir, I.; Amin, I.; Farooq, S. and Sultan, S.M. (2005). Effect of cytokinins on the senescence and longevity of isolated flowers of day lily (Hemerocallis fulva) cv. Royal crown sprayed with cycloheximide. Acta. Hort., 669:395-403.

Hashemabadi, D.; Torkashvand, A.M.; Kaviani, $\quad$ B.; Bagherzadeh, M.; Rezaalipour, M. and Zarchini, M. (2015). Effect of Mentha pulegium extract and 8hydroxyl quinolne sulfate to extend the quality and vase life of rose (Rosa hybrid) cut flower. J. Environ. Biol., 36:215-220.

He, S.; Joyce, D.C.; Irving, D.E. and Faragher, J.D. (2006). Stem end blockage in cut Grevillea 'Crimson Yul-lo' inflorescences. Postharvest Biol. Technol., 41:78-84.

Jeyakumar, A.K.; Jawaharlal, M.N.; Vijay, G.S. and Sellappan, H.G. (2016). Effects of concentration of daminozide and maleic hydrazide on growth, physiology and flowering of spray chrysanthemum var. Punch. Inter. J. of Hort. and Flor., 4(3):224-232.

Kahar, S.A. (2008). Effects of frequency and concentration of B-9 (daminozide) on growth, flowering and flower quality of Reagan Sunny chrysanthemum (Chrysanthemum morifolium Ramat.). Acta Hort., 788:141-148.

Ketsa, S. and Sribunma, R. (1985). Pulsing effect of sucrose and sodium benzoate on senescence of 'Christian Dior' cut roses. Kasetsart J. (Nat. Sci.), 19:261-264.

Khalid, M.E. (2012). Evaluation of several holding solutions for prolonging vase-life and keeping quality of cut sweet pea flowers (Lathyrus odoratus L.). Saudi J. Biol. Sci., 19(2):195-202.

Larsen, P.; Harbo, A.; Klungroun, S. and Ashein, T. (1962). On the biogenesis of some indole compounds in Acetobacte rxylinum. Physiol. Plant, 15:552-565.

Lichtenthaler; H.K. and Wellburn, A.R. (1985). Determination of total carotenoids and chlorophylls A and B of leaf in different solvents. Biol. Soc. Trans., 11:591-592.

Lü, P.; He, S.; Liu, J.; Cao, J. and Joyce, D.C. (2009). A new apparatus for continuous automatic measurement of water relations in stems of cut flowers. Intl. Conf. Plant Vascular Biol (Agr. 2009, Abst. Book, Beibei, China), 314315.

Macnish, A.J.; Leonard, R.T. and Nell, T.A. (2008). Treatment with chlorine dioxide extends the vas life of selected cut flowers. Postharvest Biol. Technol., 50:197-207.

Madhavi, B. (2016). Studies on Dry Cool Storage and Pulsing Treatments in Gerbera (Gerbera jamesonii Hook) Cut Flowers for Export. Thesis Ph. Univ. of Agric. Scie., Dharwad, Indian.

Mohammadi, S. and Mosirat, M. (2011). Effect of some chemical compounds on the vase life of two cultivars of cut roses. J. Ornam. and Hort. Plants, 1(2):123-128.

Mohy Eldeen, N. (2012). Vase life extension of rose cut flowers (Rosa Hybirida) as influenced by silver nitrate and sucrose pulsing. Am. J. Agri. \& Biol. Sci., 6(1):128-133.

MSTAT Computer Program (1985), Software program for design, management and analysis experimental (version 4.0), Michigan State Univ. 


\section{E.A. Khella et al.}

Mwangi, M.; Chatterjee, S.R. and Bhattacharjee, S.K. (2003). Changes in the biochemical constituents of Golden gate cut rose petals as affected by precooling with ice cold water spray, pulsing and packaging. J. Plant Biol., 30:95-97.

Plaats-Niterink and Van Der, A.J. (1981). Monograph of the Genus Pythium. studies in Mycology No. 20, 242 pp. Centraalbureau Voor Schimmel. Cultures, Baarn, Netherland.

Pun, U.K. and Ichimura, K. (2003). Role of sugars in senescence and biosynthesis of ethylene in cut flowers. JARQ, 4:219224.

Rabiza-Świder, J.; Skutnik, E.; Jędrzejuk, A. and Łukaszewska, A. (2017). Extending the vase life of cut clematis flowers. Acta Sci. Pol. Hortorum Cultus, 16(1):51-60.

Reddy, T.C.N. and Raju, B. (1988). Impregnating cut rose stem with nickel increases in vase life. Hort. Abst., 59:2360.

Saichol, K.; Yenchit, P. and Sutruedee, P. (1995). Mode of action of $\mathrm{AgNO}_{3}$ in maximizing vase life of Dendrobium 'Pompadour' flowers. Postharvest Biology and Technology. 5 (1-2):109-117.

Salim, H.H.; Fayek, M.A. and Sweidan, A.M. (1978). Reproduction of Bircher apple cultivar by layering. Ann Agic., Sci., Moshtohor, 78 (9):157-166.

Singh, A.K. and Tiwari, A.K. (2002). Effect of pulsing on postharvest life of Rose $\mathrm{v}$.
Doris Tystermann. South-Indian-Hort., 50:140-144.

Singh, U.C. and Bhattacharjee, S.K. (2000). Effect of pulsing with silver nitrate, STS and DMSO on Raktagandha cut roses. J. of Ornamen. Horti., New Series, 3(2):131-132.

Snedecor, G.W. and Cochran, W.G. (1990). Statistical Methods. 11th Ed. Iowa State Univ., Press. Ames, Iowa, U.S.A.

Suong, T.T.H.; Byung-Chun, I.; HyungWon, C.; Yeon-Ok, J. and Jin-Hee, L. (2017). Assessment of pretreatment solutions for improving the vase life and postharvest quality of cut roses (Rosa hybrida L. 'Jinny'). Flower Res. J., 25(3):101-109.

Vigna, R.; Devecchi, A. and Accati, E. (1999). Keeping cut flowers of Delphinium and Limonium. Colture Protette, 28(10):71-78.

Waller, A. and Duncan, D.B. (1969). Multiple ranges and multiple tests. Biomet., 11:1-24.

Wikipedia (2017). The Free Encyclopedia, Limonium. www.google.com.

Yann, R.C.; Hui, J.H. and Fang, M.W. (2000). The research of postharvest handling and transport in container with water on Limonium 'Misty blue'. Council of Agriculture Science and Technology, 68:1-18. 


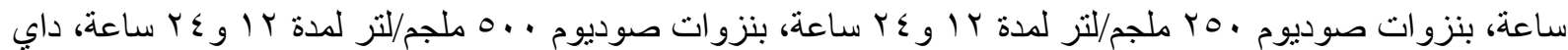

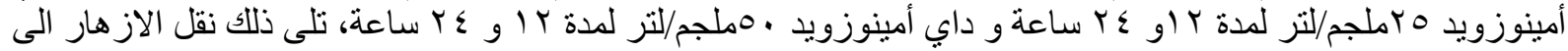

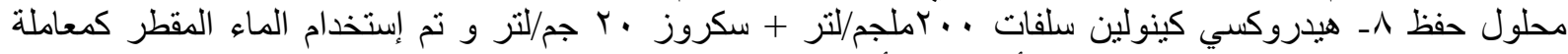

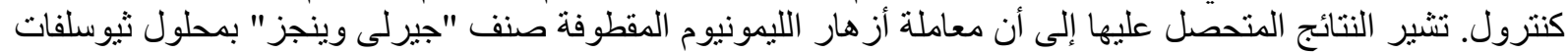

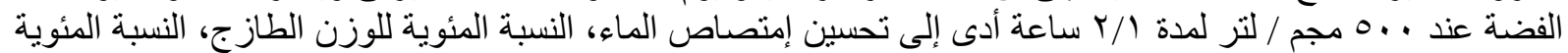

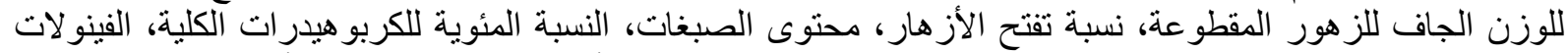

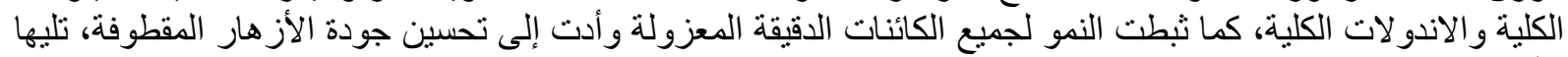

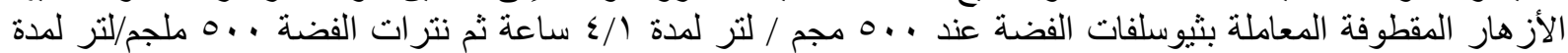
T// ساعة، مقارنة بمحاليل الحفظ الأخري. 
